\title{
Erratum to: cluster randomized evaluation of adolescent girls empowerment Programme (AGEP): study protocol
}

\author{
Paul C. Hewett ${ }^{1 *}$, Karen Austriann ${ }^{2}$, Erica Soler-Hampejsek ${ }^{3,4}$, Jere R. Behrman ${ }^{5}$, Fiammetta Bozzani ${ }^{6}$ and \\ Natalie A. Jackson-Hachonda ${ }^{7}$
}

\section{Erratum}

After publication of the article [1], it has been brought to our attention that some of the statistical data presented regarding the DHS data in the second paragraph of the background section is incorrect. The authors would like to note the following changes.

1) The following statistics were accidentally reversed: "The prevalence in rural areas is nearly double that of urban areas for both early marriage (39\% versus $22 \%$ ) and early childbearing (42\% versus $21 \%$ )." This sentence should read: "The prevalence in rural areas is nearly double that of urban areas for both early marriage ( $42 \%$ versus $21 \%$ ) and early childbearing (39\% versus $22 \%) . "$

2) The statistic on the prevalence of sexual initiation in the following sentence was incorrect: "For instance, the median age of sexual debut is 17.7 years, approximately 1 year prior to marriage, and the prevalence of sexual initiation among $15-19$ year olds is $27 \%$. This sentence should read": For instance, the median age of sexual debut is 17.7 years, approximately 1 year prior to marriage, and the prevalence of sexual initiation among $15-19$ year olds is $49 \%$."

\footnotetext{
Author details

'Population Council, 4301 Connecticut Avenue, Washington, D.C 2008, USA.

${ }^{2}$ Population Council, P.O. Box 17643-00500, Nairobi, Kenya. ${ }^{3}$ Population Council, One Dag Hammarskjold Plaza, New York, NY 10017, USA.

${ }^{4}$ Independent consultant, Fluvia 101, 30 4a, 08019 Barcelona, Spain.

${ }^{5}$ Departments of Economics and Sociology, University of Pennsylvania, 3718 Locust Walk, Philadelphia, P.A 19104, USA. '́London School of Hygiene and Tropical Medicine, 15-17 Tavistock Place, London WC1H 9SH, UK. ${ }^{7}$ Population Council, Plot 3670, No. 4, Mwaleshi Road, Olympia Park, 10101 Lusaka, Zambia.
}

\footnotetext{
* Correspondence: phewett@popcouncil.org

'Population Council, 4301 Connecticut Avenue, Washington, D.C 2008, USA

Full list of author information is available at the end of the article
}

Received: 27 July 2017 Accepted: 28 July 2017

Published online: 01 August 2017

\section{Reference}

1. Hewett P, Austrian K, Soler-Hampejsek E, Behrman J, Bozzani F, JacksonHachonda N. Cluster randomized evaluation of adolescent girls empowerment Programme (AGEP): study protocol. BMC Public Health. 2017;17:1. doi:10.1186/s12889-017-4280-1.

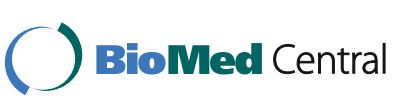

(c) The Author(s). 2017 Open Access This article is distributed under the terms of the Creative Commons Attribution 4.0 International License (http://creativecommons.org/licenses/by/4.0/), which permits unrestricted use, distribution, and reproduction in any medium, provided you give appropriate credit to the original author(s) and the source, provide a link to the Creative Commons license, and indicate if changes were made. The Creative Commons Public Domain Dedication waiver (http://creativecommons.org/publicdomain/zero/1.0/) applies to the data made available in this article, unless otherwise stated. 